\title{
Genetic testing results in Slovenian male breast cancer cohort indicate the BRCA2 7806-2A>G founder variant could be associated with higher male breast cancer risk
}

\author{
Ksenija Strojnik $^{1} \cdot$ Mateja Krajc $^{1,2} \cdot$ Vita Setrajcic Dragos $^{3} \cdot$ Vida Stegel $^{3} \cdot$ Srdjan Novakovic $^{3} \cdot$ Ana Blatnik $^{1,2}$ (I)
}

Received: 15 November 2020 / Accepted: 8 April 2021 / Published online: 23 April 2021

(c) The Author(s) 2021

\begin{abstract}
Purpose To analyze the prevalence of pathogenic/likely pathogenic variants (P/LPVs) in BRCA1 and BRCA2 genes in the largest cohort of Slovenian male breast cancer $(\mathrm{MBC})$ patients to date and to explore a possible correlation between the Slovenian founder variant $B R C A 2: c .7806-2 \mathrm{~A}>\mathrm{G}$ and predisposition to $\mathrm{MBC}$.

Methods We performed a retrospective analysis of $81 \mathrm{MBC}$ cases who underwent genetic counseling and/or testing between January 1999 and May 2020. To explore a possible genotype-phenotype correlation, we performed additional analyses of 203 unrelated families with P/LPVs in BRCA2 and 177 cases of female breast cancer (FBC) in carriers of P/LPVs in BRCA2. Results Detection rate of P/LPVs in the BRCA1 and BRCA2 genes was $24.7 \%$ (20/81) with $95 \%$ of them in $B R C A 2$ gene. The only two recurrent P/LPVs were BRCA2:c.7806-2A $>\mathrm{G}$ and BRCA2:c.3975_3978dupTGCT (9 and 5 MBC cases, respectively). In families with $B R C A 2: c .7806-2 \mathrm{~A}>\mathrm{G}$, the incidence of $\mathrm{MBC}$ cases was higher compared to families with other $\mathrm{P} /$ LPVs in BRCA2; however, the difference did not reach statistical significance (17.8\% vs. 8.9\%, $p=0.105)$. BRCA2:c.7806$2 \mathrm{~A}>\mathrm{G}$ was detected in both families with multiple cases of MBC. This splice-site variant represented a significantly higher proportion of all BRCA2 P/LPVs detected in MBC carriers compared to FBC carriers (47.4\% vs. 26\%, $p=0.049$ ).

Conclusion We observed a high mutation detection rate and conclude this may be due to the prevalent BRCA2:c.7806-2A $>\mathrm{G}$ variant in Slovenia. Our results indicate a possible association between this variant and higher risk of breast cancer in males compared to other identified P/LPVs in BRCA2.
\end{abstract}

Keywords Male breast cancer $\cdot B R C A 1 \cdot B R C A 2 \cdot$ Hereditary breast cancer $\cdot$ Founder variant

\section{Introduction}

Male breast cancer (MBC) is a rare disease, comprising up to $1 \%$ of all breast cancers and up to $1 \%$ of all cancers in males [1-3]. Age-adjusted incidence rate in Slovenia is reported to be 1.1 per 100,000 and is in line with incidence rates reported in other Caucasian populations [2, 4, 5]. Various demographic, environmental, hormonal, and genetic factors have been associated with MBC $[2,6]$. Among genetic

Ana Blatnik

ablatnik@onko-i.si

1 Institute of Oncology, Cancer Genetics Clinic, Ljubljana, Slovenia

2 University of Ljubljana, Ljubljana, Slovenia

3 Department of Molecular Diagnostics, Institute of Oncology, Ljubljana, Slovenia factors, mutations in BRCA1 and, especially, $B R C A 2$ genes are the most clearly established predispositions [2]. Genetic testing is recommended for all MBC patients in order to guide screening recommendations for other types of cancer and to identify other family members at risk $[1,7]$, as well as for treatment with PARP (poly-ADP ribose polymerase) inhibitors in metastatic settings according to the American Society of Clinical Oncology 2020 guidelines [8].

In 2008, Besic together with members of our group published first results of genetic testing in a small cohort of 25 Slovenian MBC patients and reported a high prevalence of $16 \%$ of pathogenic/likely pathogenic variants (P/LPVs) in $B R C A 2$ [9]. In three out of four MBC carriers of P/LPVs in $B R C A 2$, the highly recurrent Slovenian founder splice-site variant $B R C A 2$ :c.7806-2A $>\mathrm{G}$ (formerly known as IVS16$2 A>G$ ) was detected $[10,11]$. A group from Aviano, Italy, also reported this variant as recurrent in northeast part of 
Italy and suggested an association between this splice-site BRCA2 variant and risk of breast cancer in males [12-14].

The aim of our study was to analyze the prevalence of $\mathrm{P} /$ LPVs in BRCA1 and BRCA2 genes in the largest cohort of Slovenian MBC patients to date. We performed a retrospective analysis of all MBC cases who were referred to our Cancer Genetic Clinic at the Institute of Oncology Ljubljana, Slovenia, since its inception in 1999. Our primary objective was to re-evaluate the high detection rate of P/LPVs in BRCA1 and BRCA2 genes in a small cohort of Slovenian MBC patients, reported previously by Besic et al. in 2008 [9]. In addition, we wanted to document the spectrum of all P/LPVs as well as possible difference between carriers and non-carriers of P/LPV in BRCA1 and BRCA2 genes. Our secondary objective was to explore a possible correlation between the BRCA2:c.7806-2A $>\mathrm{G}$ variant and predisposition to MBC compared to other $B R C A 2 \mathrm{P} / \mathrm{LPV}$ s identified in our cohort. We also evaluated certain clinical characteristics of $\mathrm{MBC}$ in carriers of $B R C A 2: \mathrm{c} .7806-2 \mathrm{~A}>\mathrm{G}$ compared to other P/LPVs in BRCA2.

\section{Methods}

\section{MBC cohort and data collection}

We performed a retrospective analysis of MBC cases identified in the Cancer Genetics Clinic's database at the Institute of Oncology Ljubljana, the only comprehensive cancer center in Slovenia. Our cohort is unselected for family history of cancer, since MBC has always been one of the independent inclusion criteria for genetic testing at the Institute [11]. All MBC cases referred to our Clinic since the introduction of genetic counseling and testing in 1999 up to May 2020 who opted for genetic testing were included. Only P/ LPVs in BRCA1 and BRCA2 genes were analyzed.

For the purpose of this study, positive family history for hereditary breast and ovarian cancer syndrome (HBOCrelated) cancers was defined as a family history of female breast, ovarian, prostate, and/or pancreatic cancer in first and/or second-degree relatives. As part of our routine clinical protocol, all probands are required to report their family history of cancer, which is then verified in the Cancer Registry of Republic of Slovenia, a national system of mandatory reported cancer cases, established in 1950. Also, we used this database to check if the MBC patients in our cohort had been diagnosed with any other cancers.

Information on relevant $\mathrm{MBC}$ clinical and pathological characteristics was retrieved from the Institute's electronic database and patients' medical records. We applied surrogate definitions of intrinsic subtypes of breast cancer as defined by the St. Galen International Expert Consensus 2013 [15].
For the purpose of exploring possible genotype-phenotype correlation between the BRCA2:c.7806-2A $>\mathrm{G}$ variant and predisposition to $\mathrm{MBC}$ compared to other $B R C A 2 \mathrm{P} /$ LPVs identified at our Institute, we performed an additional analysis of all unrelated families with P/LPVs in BRCA2 detected at our Institute since 1999. We recorded all cases of MBC in these families. Also, all cases of breast cancer in female carriers of P/LPVs in BRCA2 were identified from the Cancer Genetics Clinic's database.

We obtained the approval for our analysis from the Institute's Committee for Medical Ethics (\#ERIDEK-0069/2020).

\section{Genetic testing methods}

Genetic testing was performed at the Department of Molecular Diagnostics at the Institute as well as other laboratories [11]. Together, we identified $81 \mathrm{MBC}$ cases. Different genetic testing methods were used. In $55 \mathrm{MBC}$ cases, genetic testing with next-generation sequencing (NGS) was performed on blood samples. Of these, 54 were tested using NGS of targeted panels Illumina's TruSight Cancer Panel or TruSight Hereditary Cancer Panel [16]. Large intragenic deletions in BRCAl and $B R C A 2$ genes were detected from NGS data with copy number analysis using SeqNext v4.4.0 (JSI medical systems) or with multiplex ligation-dependent probe amplification (MLPA). Identified P/LPVs in BRCA1 and BRCA2 were confirmed using Sanger sequencing or MLPA analysis from separate blood samples. In one patient, clinical exome sequencing was performed at another laboratory as previously described by Bergant et al. [17]. In 15 MBC cases, who were tested prior to the introduction of NGS in 2014, only a limited mutational screen for the six highly recurrent P/LPV in BRCA1 and BRCA2 in Slovenian population (c.7806-2A $>\mathrm{G}$ in BRCA2; c.5266dupC, c. $1687 \mathrm{C}>$ T. c. $191 \mathrm{G}>\mathrm{A}, \mathrm{c} .181 \mathrm{~T}>\mathrm{G}$ and c.181 T $>\mathrm{A}$ in $B R C A 1)$ was performed. In these, denaturing gradient gel electrophoresis (DDGE) for exon 4, part of exon 10 and exon 19 of BRCA1, DDGE for exon 17 of $B R C A 2$, and in two cases additionally protein truncation test (PTT) for exon 10 of $B R C A 1$ and exon 11 of $B R C A 2$ were used as detailed elsewhere by our group [11]. In four MBC cases, complete screening of all $B R C A 1$ and $B R C A 2$ exons with combination of high-resolution melting (HRM), DDGE, and Sanger sequencing methods as well as MLPA for detecting large genomic deletions was performed as previously described $[18,19]$. Out of 55 patients who underwent NGS testing, 42 were previously untested and 13 had already tested negative with previously performed genetic screening using DGGE, HRM, PPT, or Sanger sequencing; all living MBC patients who tested negative prior to the introduction NGS at our Institute in 2014 were re-contacted, and 13 of them responded and opted for re-testing 
with NGS. In three MBC cases, only Sanger sequencing was performed to determine known familial pathogenic variants in BRCA2 gene. In four MBC cases, NGS testing (TruSight Tumor 170) was performed on archived formalin-fixed paraffin-embedded (FFPE) tissue samples (two samples were obtained from tumor tissue and two from non-tumor) as previously described by Klancar et al. [20]. Flow chart of genetic testing methods performed as well as detection of P/LPVs in BRCA1 and BRCA2 with different testing methods used is depicted in the Fig. 1.

\section{Statistical analysis}

We used descriptive statistics to describe relevant MBC patients' clinical, pathological, and genetic as well as their families' characteristics. Association between categorical variables was evaluated using Pearson's chisquared or Fisher's exact test, as appropriate. To compare means, we used the independent-samples t-test. All significance tests were two-sided using an alpha level of 0.05 . The statistical analysis was performed with the licensed IBM SPSS Statistics software, version 25.

\section{Results}

\section{MBC cohort characteristics}

We identified 81 MBC cases from 80 unrelated families who underwent genetic counseling and/or testing at our Institute between January 1999 and May 2020. Pathological and clinical characteristics of MBC cases are summarized in Table 1. Patients were diagnosed with breast cancer between 1970 and 2019 with half of them diagnosed prior to 2011. Excluding non-melanoma skin cancer and contralateral breast cancer, 19/81 (23.5\%) MBC patients had a personal history of additional malignant primary tumors. Melanoma was reported in four MBC patients, colorectal cancer in three, prostate cancer in three, renal cell carcinoma in two, hematological malignancy in two, lung cancer in one, conjunctival squamous cell carcinoma in one, unknown primary in one, while two patients had multiple additional primary tumors (prostate and gastric cancer; prostate and lung cancer). In 31/80 (38.7\%) of unrelated families with MBC cases, there was a family history of female breast, ovarian, prostate, and/or pancreatic cancer, and in 2/80 (2.5\%), there was a family history of male breast cancer (a brother in one and a father in the other).

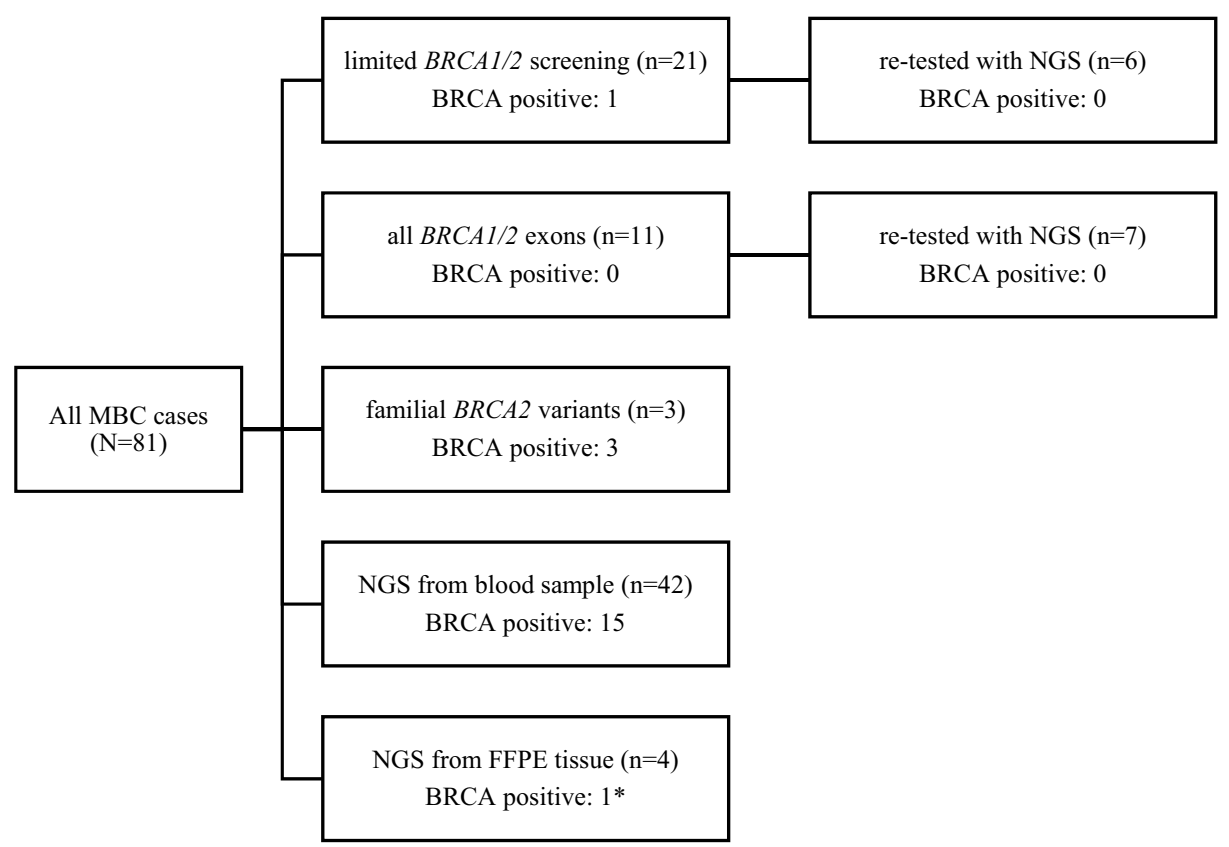

BRCA positive: P/LPV was detected in either BRCA1 or BRCA2 gene; NGS: next generation sequencing; MBC: male breast cancer; $* \mathrm{P} / \mathrm{LPV}$ detected from a non-tumor FFPE tissue

Fig. 1 Flow chart of genetic testing methods used and detection of P/LPVs in BRCA1 and BRCA2. BRCA positive: P/LPV was detected in either $B R C A 1$ or $B R C A 2$ gene; NGS: next-generation sequencing; MBC: male breast cancer; *P/LPV detected from a non-tumor FFPE tissue 
Table 1 Characteristics of 81 male breast cancer cases

\begin{tabular}{ll}
\hline Characteristic & $\mathrm{N}(\%)$ \\
\hline Age (median) & \\
At diagnosis & 62 (range 17-87) \\
At genetic testing & 66 (range 39-88) \\
MBC histology & \\
DCIS & $4(4.9)$ \\
IDC & $70(86.4)$ \\
ILC & $1(1.2)$ \\
Other & \\
Stage & $6(7.5)$ \\
0 & \\
I-III & $4(4.9)$ \\
IV & $72(88.9)$ \\
Intrinsic subtypes $(n=55)^{\mathrm{b}}$ & $5(6.2)$ \\
Luminal A & \\
Luminal B & $20(36.4)$ \\
Luminal B HER2 + & $26(47.3)$ \\
HER2 + & $7(12.7)$ \\
Basal & $1(1.8)$ \\
Contralateral MBC & $1(1.8)$ \\
Yes & \\
No & $2(2.5)$ \\
Relapse & $79(97.5)$ \\
Yes & \\
No & $17(21)$ \\
Primarily metastatic & $59(72.8)$ \\
\hline & $5(6.2)$ \\
\hline
\end{tabular}

DCIS ductal carcinoma in situ, IDC invasive ductal carcinoma, ILC invasive lobular carcinoma

${ }^{a}$ Mixed IDC and ILC (1), secretory (2), mucinous (1), encapsulated papillary with invasion (1), only cytology available (1)

${ }^{\mathrm{b}}$ Data not available for 22 invasive MBC cases

\section{Detection rate and spectrum of P/LPVs in BRCA1 and BRCA2}

Detection rate of P/LPVs in the $B R C A 1$ and $B R C A 2$ genes was $24.7 \%$ (20/81), with $19 / 81(23.5 \%)$ detected in BRCA2 and 1/81 (1.2\%) in BRCA1. Among all, 95\% $(19 / 20)$ of identified P/LPVs were in BRCA2 gene. Spectrum of detected P/LPVs together with clinical and pathological characteristics of MBC cases, and personal and family history of additional cancers are detailed in Table 2. Detection rate in MBC cases with a family history of other HBOC-related cancers in first- and/or second-degree relatives was significantly higher compared to those without (43.7\% (14/32) vs. $12.2 \%(6 / 49), p=0.001)$.

\section{Carriers vs. non-carriers}

MBC patients who were carries of P/LPVs in BRCAl or $B R C A 2$ were more likely to report a family history of other HBOC-related cancers in first- and/or second-degree relatives $(70 \%$ vs. $29.5 \%, p=0.001)$. While none of the noncarriers developed contralateral breast cancer, both men with bilateral breast cancer in our cohort were carriers of deleterious variants in BRCA2 ( $p=0.059)$. In both unrelated families (2/80) with multiple MBC cases , deleterious variants in BRCA2 were identified $(p=0.054)$. Excluding non-melanoma skin cancer and contralateral breast cancer, carriers of deleterious variants in BRCAl or BRCA2 did not have a statistically significant difference in personal history of other cancers $(20 \%$ vs. $24.6 \%, p=0.77)$ or mean age at diagnosis of breast cancer ( 60.4 vs. 61.2 years, $p=0.81$ ) compared to non-carriers.

\section{Genotype-phenotype correlation}

Two out of eight (25\%) of identified P/LPVs in $B R C A 1$ and BRCA2 were recurrent. The two recurrent ones were BRCA2:c.7806-2A $>\mathrm{G}$ p.? and BRCA2:c.3975_3978dupTGCT p.(Ala1327Cysfs*4), detected in 9 and $5 \mathrm{MBC}$ cases, respectively (Table 2). The first one represented $47.4 \%(9 / 19)$ and the second one $26.3 \%$ (5/19) of all P/LPVs in BRCA2 detected in our MBC cohort.

Since the beginning of genetic counseling and testing at our Institute in 1999, 67 different P/LPVs in BRCA2 have been detected in 203 unrelated families: 24 variants were recurrent and 43 were detected only once. The two most common recurrent variants were BRCA2:c.7806-2A $>\mathrm{G}$ p.? and BRCA2:c.3975_3978dupTGCT p.(Ala1327Cysfs*4), which were present in $22.2 \%$ and $15.8 \%$ of the BRCA2positive families, respectively. MBC cases were detected in $10.8 \%$ (22/203) of non-related $B R C A 2$ families. In families with BRCA2:c.7806-2A $>\mathrm{G}$, the incidence of MBC cases was higher compared to families with other P/LPVs in BRCA2; however, the difference did not reach statistical significance ( $17.8 \%$ vs. $8.9 \%, p=0.105)$. Furthermore, BRCA2:c.7806-2A $>\mathrm{G}$ was detected in both families with multiple cases of MBC in first- and/or second-degree relatives.

MBC patients, who were carriers of BRCA2:c.7806$2 \mathrm{~A}>\mathrm{G}$, did not experience higher incidence of other cancers, excluding non-melanoma skin cancer and contralateral breast cancer ( $22.2 \%$ vs. $23.6 \%, p=1.0)$. Also, mean age at diagnosis of breast cancer did not differ between carriers of BRCA2:c.7806-2A $>\mathrm{G}$ and others (59.6 vs. 61.2 years, $p=0.72$ ). Two MBC patients had bilateral breast cancer and both were carriers of P/LPVs: one of them BRCA2:c.7806$2 \mathrm{~A}>\mathrm{G}$ and the other BRCA2:c.6445_6446delAT (Table 2). 
Table 2 Spectrum of detected P/LPVs in BRCA1 and BRCA2

\begin{tabular}{|c|c|c|c|c|c|c|}
\hline \multirow{2}{*}{$\begin{array}{l}\text { MBC } \\
\text { No }\end{array}$} & \multirow[t]{2}{*}{ Gene } & \multicolumn{2}{|l|}{ HGVS nomenclature } & \multirow{2}{*}{$\begin{array}{l}\text { MBC characteristics: histol- } \\
\text { ogy, intrinsic subtype } \\
\text { (age at diagnosis) }\end{array}$} & \multirow{2}{*}{$\begin{array}{l}\text { Other cancers } \\
\text { (age at diagnosis) }\end{array}$} & \multirow{2}{*}{$\begin{array}{l}\text { Family history of HBOC- } \\
\text { related cancers (age at } \\
\text { diagnosis) }\end{array}$} \\
\hline & & Nucleotide change & Protein change & & & \\
\hline 1 & $B R C A 1$ & e4-9del & p.? & $\begin{array}{l}\text { IDC, luminal A } \\
\text { (48) }\end{array}$ & - & - \\
\hline 2 & $B R C A 2$ & c. $7806-2 \mathrm{~A}>\mathrm{G}$ & p.? & $\begin{array}{l}\text { IDC, luminal B } \\
\text { (64) }\end{array}$ & - & $\begin{array}{l}\text { MBC (64); } 4 \text { FBC } \\
\quad(30,61,70,79) ; \text { bil FBC }(68)\end{array}$ \\
\hline 3 & $B R C A 2$ & c. $7806-2 \mathrm{~A}>\mathrm{G}$ & p.? & $\begin{array}{l}\text { DCIS } \\
(56)\end{array}$ & - & - \\
\hline 4 & $B R C A 2$ & c. $7806-2 \mathrm{~A}>\mathrm{G}$ & p.? & $\begin{array}{l}\text { IDC, luminal B HER2 + } \\
\text { (64) }\end{array}$ & - & $\begin{array}{l}\text { MBC }(64) ; 4 \text { FBC } \\
\quad(30,61,70,79) ; \text { bil FBC }(68)\end{array}$ \\
\hline 5 & $B R C A 2$ & c. $7806-2 \mathrm{~A}>\mathrm{G}$ & p.? & $\begin{array}{l}\text { IDC, luminal B } \\
\text { (58) }\end{array}$ & M (68) & $\begin{array}{l}\text { MBC (72); bil FBC }(43,50) \\
\text { FBC }(62)\end{array}$ \\
\hline 6 & $B R C A 2$ & c. $7806-2 \mathrm{~A}>\mathrm{G}$ & p.? & $\begin{array}{l}\text { IDC, luminal B } \\
\text { (38) }\end{array}$ & - & FBC (65) \\
\hline 7 & $B R C A 2$ & c. $7806-2 \mathrm{~A}>\mathrm{G}$ & p.? & $\begin{array}{l}\text { Bil MBC: IDC, luminal B } \\
(62,66)\end{array}$ & $\mathrm{M}(50)$ & - \\
\hline 8 & $B R C A 2$ & c. $7806-2 \mathrm{~A}>\mathrm{G}$ & p.? & $\begin{array}{l}\text { IDC, luminal B } \\
\text { (55) }\end{array}$ & - & $\begin{array}{l}\mathrm{FBC}(48) ; 2 \operatorname{PrC}(61,64) ; 2 \\
\quad \operatorname{PaC}(74,77)\end{array}$ \\
\hline 9 & $B R C A 2$ & c. $7806-2 \mathrm{~A}>\mathrm{G}$ & p.? & $\begin{array}{l}\text { IDC, luminal A } \\
(65)\end{array}$ & - & - \\
\hline 10 & $B R C A 2$ & c. $7806-2 \mathrm{~A}>\mathrm{G}$ & p.? & $\begin{array}{l}\text { Masive DCIS with microinva- } \\
\text { sion (74) }\end{array}$ & - & - \\
\hline 11 & $B R C A 2$ & c.3975_3978dupTGCT & p.Ala1327Cysfs* & $\begin{array}{l}\text { Mixed IDC and ILC } \\
(50)\end{array}$ & - & OC (40); FBC (59) \\
\hline 12 & $B R C A 2$ & c.3975_3978dupTGCT & p.Ala1327Cysfs* & $\begin{array}{l}\text { IDC, luminal B } \\
\text { (68) }\end{array}$ & - & $\operatorname{FBC}(30) ; \operatorname{PrC}(72)$ \\
\hline 13 & $B R C A 2$ & c.3975_3978dupTGCT & p.Ala1327Cysfs* & $\begin{array}{l}\text { IDC } \\
(63)\end{array}$ & - & $2 \operatorname{FBC}(53,59)$ \\
\hline 14 & $B R C A 2$ & c.3975_3978dupTGCT & p.Ala1327Cysfs* & $\begin{array}{l}\text { IDC, luminal B HER } 2+ \\
(50)\end{array}$ & - & - \\
\hline 15 & $B R C A 2$ & c.3975_3978dupTGCT & p.Ala1327Cysfs* & $\begin{array}{l}\text { Masive DCIS with microinva- } \\
\text { sion }(80)\end{array}$ & - & 3 FBC $(41,54,65)$ \\
\hline 16 & $B R C A 2$ & c.2808_2811delACAA & p.Ala938Profs* & $\begin{array}{l}\text { IDC, luminal A } \\
(60)\end{array}$ & $\mathrm{RC}(52)$ & $5 \mathrm{FBC}(40,40, ?)$ \\
\hline 17 & $B R C A 2$ & c.5560_5561delGT & p.Val1854Phefs* & $\begin{array}{l}\text { IDC, luminal B } \\
\text { (64) }\end{array}$ & $\operatorname{PrC}(51)$ & OC (62) \\
\hline 18 & $B R C A 2$ & c.6445_6446delAT & p.Ile2149fs* & $\begin{array}{l}\text { Bil MBC: IDC, luminal A } \\
\text { (62) and IDC, luminal B } \\
(64)\end{array}$ & - & FBC (49) \\
\hline 19 & $B R C A 2$ & c.6491_6494delAGTT & p.Gln2164Argfs* & $\begin{array}{l}\text { IDC luminal B } \\
(68)\end{array}$ & - & $5 \mathrm{FBC}(37,43,50,52,62)$ \\
\hline 20 & $B R C A 2$ & e2-27del & p.? & $\begin{array}{l}\text { Encapsulated papillary with } \\
\text { invasion (59) }\end{array}$ & - & $\mathrm{FBC}(53), \operatorname{PrC}(65) ; \mathrm{PaC}(57)$ \\
\hline
\end{tabular}

$I D C$ invasive ductal carcinoma, DCIS ductal carcinoma in situ, $I L C$ invasive lobular carcinoma, Bil bilateral, $M$ melanoma, $R C$ renal cell cancer, $\operatorname{PrC}$ prostate cancer, $\mathrm{PaC}$ pancreatic cancer, $O C$ ovarian cancer.

From our database, we also identified all 177 female carriers of P/LPVs in BRCA2 who developed breast cancer. The most common P/LPV in these women was the recurrent BRCA2:c.7806-2A $>\mathrm{G}$ detected in $26 \%(46 / 177)$ of these women, followed by the
BRCA2:c.3975_3978dupTGCT detected in $14.1 \%$ (25/177). The splice-site variant represented a significantly higher proportion of all $B R C A 2 \mathrm{P} / \mathrm{LPV}$ s detected in MBC carriers compared to female breast cancer (FBC) carriers $(47.4 \%$ vs. $26 \%, p=0.049)$. 


\section{Discussion}

In our study, we aimed to analyze the prevalence of $\mathrm{P} /$ LPVs in BRCA1 and BRCA2 genes in the largest cohort of Slovenian MBC patients to date. Our primary objective was to re-evaluate the high detection rate of P/LPVs in BRCA1 and BRCA2 as previously reported [9]. We hypothesized the detection rate could be even higher, as more accurate genetic screening methods including nextgeneration sequencing have been implemented in clinical practice since then. Here, we report a high detection rate (24.7\%) of P/LPVs in BRCA2 (23.5\%) and BRCA1 (1.2\%) in the largest cohort of Slovenian MBC patients $(n=81)$. Our cohort is very similar to other published cohorts regarding the age and stage at diagnosis [21-24], histology, and intrinsic subtypes of breast cancer [2, 23, 25-27]. As we predicted, the detection rate is higher than the first reported detection rate of $16 \%(4 / 16)$ in a small cohort of Slovenian MBC patients in 2008 [9]. Then, only limited genetic screening was performed for highly recurrent $\mathrm{P} /$ LPVs in BRCA1 and BRCA2 detected in Slovenian HBOC families [11] and extended genetic analysis was limited only to those with a substantial family history of breast and/or ovarian cancer [9].

Recently published detection rates of P/LPVs in BRCAI and/or $B R C A 2$ in unselected MBC patients range between $7.8 \%$ and $22 \%$ in smaller cohorts [28-32]. In two of the largest recently published cohorts, consisting of $382 \mathrm{MBC}$ patients in the collaborative Italian Multicenter Study and 708 mixed population MBC patients tested by Ambry Genetics, California, reported detection rates were 13\% and $9 \%$, respectively $[33,34]$. Not surprisingly, most deleterious variants were attributed to $B R C A 2$ and only $1 \%$ or less to $B R C A 1$, as also seen in our cohort [28, 30-34].

Reported family history of other HBOC-related cancers in 80 unrelated families with MBC cases in our cohort was similar to others (38.7\% in our cohort vs. $32 \%$ to $39 \%$ reported in other unselected MBC cohorts) [30, 32, 33]. We observed a particularly high (43.7\%) detection rate in those with a family history of other HBOC-related cancer in first- and/or second-degree relatives. Observed detection rates in our study are in line with high detection rates observed in MBC patients from populations with founder effects [35-37].

Interestingly, almost one third of MBC patients, who were carriers of P/LPVs in BRCA1 or BRCA2, had no family history of other HBOC-related cancers in their firstand/or second-degree relatives. The detection rate in these was high $(12.2 \%)$. However, these results are similar to those published by other groups who reported between $3.6 \%$ and $13 \%$ detection rates in MBC patients without any family history of breast cancer [23, 32, 37, 38]. Our findings confirm that genetic testing should be offered to all MBC patients regardless of their family history of other cancers.

In our cohort of MBC patients, the splice-site c.7806$2 \mathrm{~A}>\mathrm{G}$ in $B R C A 2$ was the most common deleterious variant detected and represented almost half of all variants in $B R C A 2$ gene. Our group previously reported this variant as a founder Slovenian mutation [10,11]. It is the most common pathogenic variant in the BRCA2 gene, detected in Slovenian HBOC families [18], most commonly detected in the central Osrednjeslovenska and eastern Savinjska region of Slovenia [39]. Different published reports on functional analysis of the BRCA2:c.7806-2A > G variant showed at least three abnormal transcripts: skipping of entire exon 17, out-offrame skipping of 20 nucleotides at 5 '-end exon 17 and inframe skipping of 69 nucleotides at 5 '-end exon 17 (13 out of 23 amino acids lost being strictly conserved) [14, 40, 41].

This variant was also reported as recurrent in the Italian region Friuli-Venezia-Giulia (FVG) [12-14], which neighbors the western part of Slovenia. Their analysis in 13 Italian carrier families from the FVG region demonstrated that all carriers shared a common haplotype and a common ancestor estimated around 94 generations or 2350 years ago [12]. It is not clear if the haplotype from Italian and Slovenian families is the same as such studies have never been performed [12].

Currently, there is no evidence that would clearly indicate genotype-phenotype correlation between the location of a particular variant within the $B R C A 2$ gene and predisposition to MBC [42] and no MBC-specific cluster region has been identified [43, 44]. However, it has been reported that some P/LPVs in BRCA2 were more frequent in MBC cases compared to FBC [36, 37], that male carriers of a specific variant had significantly higher lifetime risks of breast cancer compared to other variants in $B R C A 2$ [45] and that large genomic rearrangement in the $B R C A 2$ gene tends to be more frequent in families with $\mathrm{MBC}$ cases [46-48].

Possible association between the BRCA2:c.7806-2A > G variant and predisposition to MBC was first suggested by the group of researchers from Aviano. Cini et al. found that 39\% (7/18) of BRCA2:c.7806-2A $>\mathrm{G}$ families had MBC cases compared to $16 \%$ (13/80) of families with other BRCA2 P/ LPVs $(p=0.049)$ [12]. They also observed a family with this variant and three cases of MBC [12]. To explore possible genotype-phenotype correlation between the splicesite variant and predisposition to $\mathrm{MBC}$ in our cohort, we performed additional analysis of all unrelated $B R C A 2$ families documented at our Institute. This variant was the most frequent among all deleterious variants in $B R C A 2$ detected in $\mathrm{MBC}$ and $\mathrm{FBC}$ patients from these families; however, the frequency of the BRCA2:c.7806-2A $>\mathrm{G}$ variant was significantly higher among $\mathrm{MBC}$ compared to $\mathrm{FBC}$ carriers $(p=0.049)$. Also, MBC cases were reported twice as often in the BRCA2:c.7806-2A > G-positive families compared 
to families with other P/LPV in BRCA2 identified, but the difference did not reach statistical significance. However, both MBC patients in our cohort with family history of $\mathrm{MBC}$ were carriers of this splice-site variant, as was one out of two MBC patients with bilateral breast cancer. As reported by the group from Aviano [12], our analysis also suggest possible genotype-phenotype correlation between the $B R C A 2: c .7806-2 \mathrm{~A}>\mathrm{G}$ variant and predisposition to male breast cancer compared to other deleterious $B R C A 2$ variants identified at our Institute. However, both studies are small and further research on larger cohorts will be needed. Breast and prostate screening for male carriers of BRCA1/2 P/LPVs has been offered at our institution for more than 10 years. If carriers of $B R C A 2: c .7806-2 \mathrm{~A}>\mathrm{G}$ variant are in fact at greater risk for developing MBC than other $B R C A 2$ carriers, their screening recommendations could be modified in view of that risk.

There are several limitations to our study. Although our cohort represents the largest Slovenian set of MBC patients to date, the absolute number of included cases is still small. However, this is a rare disease and Slovenian population is less than 2.1 million people. As this is a retrospective analysis, our cohort is very heterogenous in view of genetic tests performed. We did not identify any P/LPV in BRCAI and $B R C A 2$ in $13 \mathrm{MBC}$ cases who were re-tested using NGS after previously testing negative using other genetic testing methods. Still, some P/LPV could have been missed since in 14 negative $\mathrm{MBC}$ cases only limited genetic screening for the six highly recurrent P/LPV in BRCAl and BRCA2 was performed [49]. Since the limited genetic screening in 14 negative MBC cases covered BRCA2:c.7806-2A > G variant but did not include BRCA2:c.3975_3978dupTGCT, which was the second most common recurrent variant identified in our cohort, this might led to an underestimated proportion of this variant compared to the c.7806-2A $>\mathrm{G}$ among MBC patients in our cohort. Also, variants in other non-BRCA1/BRCA2 genes have been linked to MBC or observed in MBC patients [34, 50], but are not reported in our study. Finally, our study was conducted in a small cohort of patients from the same clinic serving an ethnically homogenous population. Bias due to population stratification could therefore have an important effect on the results of statistical testing.

In conclusion, we observed a high mutation detection rate in this largest cohort of Slovenian MBC patients to date. As predicted, detection rate was even higher than previously reported in a much smaller cohort [9]. We conclude the observed high detection rate may be due to the prevalent Slovenian founder variant $B R C A 2:$ c.7806-2A $>$ G. As previously suggested by the group of researchers from Aviano [12], our results also indicate a possible association between this splice-site $B R C A 2$ variant and higher risk of breast cancer in males compared to other identified P/LPVs in $B R C A 2$ gene. Further research on larger cohorts is needed to explore this. Once genotype-phenotype correlations are better defined, personalized risk assessment and follow-up could be offered to carriers of genetic cancer predispositions.

Acknowledgements We thank our colleague Simona Hotujec for her assistance in data collection. The study was supported by the research program of the Slovenian research agency P3-0352.

Authors' contributions All authors contributed to the study conception and design. Data collection and analyses were performed by Ksenija Strojnik, Vita Setrajcic Dragos, and Vida Stegel. The first draft of the manuscript was written by Ksenija Strojnik and all authors commented on previous versions of the manuscript. All authors read and approved the final manuscript.

Funding No funding was received.

Data availability The dataset generated and analyzed during the current study is not publicly available due to information that could compromise research participants' privacy, but is available from the corresponding author $\mathrm{AB}$ on reasonable request.

Code availability Not applicable.

\section{Declarations}

Conflict of interest The authors declare that they have no conflicts of interest.

Ethical approval This research study was conducted retrospectively from data obtained for clinical purposes. The study was approved by the Institute's Committee for Medical Ethics (\#ERIDEK-0069/2020).

Informed consent Formal consent is not required.

Consent to participate Not applicable.

Consent to publish Not applicable.

Open Access This article is licensed under a Creative Commons Attribution 4.0 International License, which permits use, sharing, adaptation, distribution and reproduction in any medium or format, as long as you give appropriate credit to the original author(s) and the source, provide a link to the Creative Commons licence, and indicate if changes were made. The images or other third party material in this article are included in the article's Creative Commons licence, unless indicated otherwise in a credit line to the material. If material is not included in the article's Creative Commons licence and your intended use is not permitted by statutory regulation or exceeds the permitted use, you will need to obtain permission directly from the copyright holder. To view a copy of this licence, visit http://creativecommons.org/licenses/by/4.0/.

\section{References}

1. Ottini L (2014) Male breast cancer: A rare disease that might uncover underlying pathways of breast cancer. Nat Rev Cancer 14:643-644 
2. Giordano SH (2018) Breast cancer in men. N Engl J Med 378:2311-2320. https://doi.org/10.1056/NEJMra1707939

3. Gucalp A, Traina TA, Eisner JR, Parker JS, Selitsky SR, Park BH, Elias AD, Baskin-Bey ES, Cardoso F (2019) Male breast cancer: a disease distinct from female breast cancer. Breast Cancer Res Treat 173:37-48

4. Cancer in Slovenia 2017. Institute of Oncology Ljubljana, Epidemiology and Cancer Registry, Slovenian Cancer Registry, 2020. https://www.onko-i.si/fileadmin/onko/datoteke/dokumenti/RRS/ lp2017.pdf. Accessed 23 October 2020

5. Leon-Ferre RA, Giridhar KV, Hieken TJ, Mutter RW, Couch FJ, Jimenez RE, Hawse JR, Boughey JC, Ruddy KJ (2018) A contemporary review of male breast cancer: current evidence and unanswered questions. Cancer Metastasis Rev 37:599-614

6. Abdelwahab Yousef AJ (2017) Male Breast Cancer: Epidemiology and Risk Factors. Semin Oncol 44:267-272. https://doi.org/ 10.1053/j.seminoncol.2017.11.002

7. NCCN Guidelines Genetic/Familial High-risk Assessment: Breast, Ovarian, and Pancreatic. V1.2021. https://www.nccn.org/ professionals/physician_gls/pdf/genetics_bop.pdf. Accessed 9 October 2020

8. Hassett MJ, Somerfield MR, Baker ER, Cardoso F, Kansal KJ, Kwait DC, Plichta JK, Ricker C, Roshal A, Ruddy KJ, Safer JD, Van Poznak C, Yung RL, Giordano SH (2020) Management of Male Breast Cancer: ASCO Guideline. J Clin Oncol 38:18491863. https://doi.org/10.1200/JCO.19.03120

9. Besic N, Cernivc B, De Grève J, Lokar K, Krajc M, Novakovic S, Zgajnar J, Teugels E (2008) BRCA2 gene mutations in Slovenian male breast cancer patients. Genet Test 12:203-209. https://doi. org/10.1089/gte.2007.0071

10. Krajc M, De Grève J, Goelen G, Teugels E (2002) BRCA2 founder mutation in Slovenian breast cancer families. Eur J Hum Genet 10:879-882. https://doi.org/10.1038/sj.ejhg.5200886

11. Krajc M, Teugels E, Zgajnar J, Goelen G, Besic N, Novakovic S, Hocevar M, De Grève J (2008) Five recurrent BRCA1/2 mutations are responsible for cancer predisposition in the majority of Slovenian breast cancer families. BMC Med Genet 9:83. https:// doi.org/10.1186/1471-2350-9-83

12. Cini G, Mezzavilla M, Della Puppa L, Cupelli E, Fornasin A, D'Elia AV, Dolcetti R, Damante G, Bertok S, Miolo G, Maestro R, de Paoli P, Amoroso A, Viel A (2016) Tracking of the origin of recurrent mutations of the BRCA1 and BRCA2 genes in the North-East of Italy and improved mutation analysis strategy. BMC Med Genet 17:11. https://doi.org/10.1186/s12881-016-0274-6

13. Miolo GM, Della Puppa L, Santarosa M, De Giacomi C, Veronesi A, Bidoli E, Tibiletti MG, Viel A, Dolcetti R (2006) Phenotypic features and genetic characterization of male breast cancer families: Identification of two recurrent BRCA2 mutations in north-east of Italy. BMC Cancer 6:156. https://doi.org/10.1186/ 1471-2407-6-156

14. Santarosa M, Dolcetti R, Magri MD, Crivellari D, Tibiletti MG, Gallo A, Tumolo S, Della PL, Furlan D, Boiocchi M, Viel A (1999) BRCA1 and BRCA2 genes: Role in hereditary breast and ovarian cancer in Italy. Int J Cancer 83:5-9. https://doi.org/10. 1002/(SICI)1097-0215(19990924)83:1\%3c5::AID-IJC2\%3e3.0. $\mathrm{CO} ; 2-\mathrm{U}$

15. Goldhirsch A, Winer EP, Coates AS, Gelber RD, Piccart-Gebhart M, Thürlimann B, Senn HJ, Albain KS, André F, Bergh J, Bonnefoi H, Bretel-Morales D, Burstein H, Cardoso F, CastiglioneGertsch M, Coates AS, Colleoni M, Costa A, Curigliano G, Davidson NE, Di LA, Ejlertsen B, Forbes JF, Gelber RD, Gnant M, Goldhirsch A, Goodwin P, Goss PE, Harris JR, Hayes DF, Hudis CA, Ingle JN, Jassem J, Jiang Z, Karlsson P, Loibl S, Morrow M, Namer M, Osborne CK, Partridge AH, Penault-Llorca F, Perou CM, Piccart-Gebhart MJ, Pritchard KI, Rutgers EJT, Sedlmayer F, Semiglazov V, Shao ZM, Smith I, Thürlimann B,
Toi M, Tutt A, Untch M, Viale G, Watanabe T, Wilcken N, Winer EP, Wood WC (2013) Personalizing the treatment of women with early breast cancer: Highlights of the st gallen international expert consensus on the primary therapy of early breast Cancer 2013. Ann Oncol 24:2206-2223. https://doi.org/10.1093/annonc/ mdt303

16. Krivokuca A, Dragos VS, Stamatovic L, Blatnik A, Boljevic I, Stegel V, Rakobradovic J, Skerl P, Jovandic S, Krajc M, Magic MB, Novakovic S (2018) Novel BRCA1 splice-site mutation in ovarian cancer patients of Slavic origin. Fam Cancer 17:179-185. https://doi.org/10.1007/s10689-017-0022-x

17. Bergant G, Maver A, Lovrecic L, Cuturilo G, Hodzic A, Peterlin B (2018) Comprehensive use of extended exome analysis improves diagnostic yield in rare disease: A retrospective survey in 1,059 cases. Genet Med 20:303-312. https://doi.org/10.1038/gim.2017. 142

18. Stegel V, Krajc M, Zgajnar J, Teugels E, De Grève J, Hocevar M, Novakovic S (2011) The occurrence of germline BRCA1 and BRCA2 sequence alterations in Slovenian population. BMC Med Genet 12:9. https://doi.org/10.1186/1471-2350-12-9

19. Novakovic S, Milatovíc M, Cerkovnik P, Stegel V, Krajc M, Hocevar M, Zgajnar J, Vakselj A (2012) Novel BRCA1 and BRCA2 pathogenic mutations in Slovene hereditary breast and ovarian cancer families. Int J Oncol 41:1619-1627. https://doi.org/10. 3892/ijo.2012.1595

20. Klancar G, Blatnik A, Dragos VS, Vogric V, Stegel V, Blatnik O, Drev P, Gazic B, Krajc M, Novakovic S (2020) A novel germline MLH1 in-frame deletion in a Slovenian lynch syndrome family associated with uncommon isolated PMS2 loss in tumor tissue. Genes (Basel) 11(3):325. https://doi.org/10.3390/genes11030325

21. Yadav S, Karam D, Bin Riaz I, Xie H, Durani U, Duma N, Giridhar KV, Hieken TJ, Boughey JC, Mutter RW, Hawse JR, Jimenez RE, Couch FJ, Leon-Ferre RA, Ruddy KJ (2020) Male breast cancer in the United States: Treatment patterns and prognostic factors in the 21 st century. Cancer 126:26-36. https://doi.org/10. $1002 /$ cncr. 32472

22. Sarmiento S, McColl M, Musavi L, Gani F, Canner JK, Jacobs L, Fu F, Siotos C, Habibi M (2020) Male breast cancer: a closer look at patient and tumor characteristics and factors that affect survival using the National Cancer Database. Breast Cancer Res Treat 180:471-479. https://doi.org/10.1007/s10549-020-05556-y

23. Deb S, Lakhani SR, Ottini L, Fox SB (2016) The cancer genetics and pathology of male breast cancer. Histopathology 68:110-118

24. Mangone L, Ferrari F, Mancuso P, Carrozzi G, Michiara M, Falcini F, Piffer S, Filiberti RA, Caldarella A, Vitale F, Tumino R, Brustolin A, Tagliabue G, Giorgi Rossi P, Ottini L (2020) Epidemiology and biological characteristics of male breast cancer in Italy. Breast Cancer 27:724-731. https://doi.org/10.1007/ s12282-020-01068-1

25. Silvestri V, Barrowdale D, Mulligan AM, Neuhausen SL, Fox S, Karlan BY, Mitchell G, James P, Thull DL, Zorn KK, Carter NJ, Nathanson KL, Domchek SM, Rebbeck TR, Ramus SJ, Nussbaum RL, Olopade OI, Rantala J, Yoon SY, Caligo MA, Spugnesi L, Bojesen A, Pedersen IS, Thomassen M, Jensen UB, Toland AE, Senter L, Andrulis IL, Glendon G, Hulick PJ, Imyanitov EN, Greene MH, Mai PL, Singer CF, Rappaport-Fuerhauser C, Kramer G, Vijai J, Offit K, Robson M, Lincoln A, Jacobs L, Machackova E, Foretova L, Navratilova M, Vasickova P, Couch FJ, Hallberg E, Ruddy KJ, Sharma P, Kim SW, Teixeira MR, Pinto P, Montagna M, Matricardi L, Arason A, Johannsson OT, Barkardottir RB, Jakubowska A, Lubinski J, Izquierdo A, Pujana MA, Balmaña J, Diez O, Ivady G, Papp J, Olah E, Kwong A, Nevanlinna H, Aittomäki K, Perez Segura P, Caldes T, Van Maerken T, Poppe B, Claes KBM, Isaacs C, Elan C, Lasset C, StoppaLyonnet D, Barjhoux L, Belotti M, Meindl A, Gehrig A, Sutter C, Engel C, Niederacher D, Steinemann D, Hahnen E, Kast K, 
Arnold N, Varon-Mateeva R, Wand D, Godwin AK, Evans DG, Frost D, Perkins J, Adlard J, Izatt L, Platte R, Eeles R, Ellis S, Hamann U, Garber J, Fostira F, Fountzilas G, Pasini B, Giannini G, Rizzolo P, Russo A, Cortesi L, Papi L, Varesco L, Palli D, Zanna I, Savarese A, Radice P, Manoukian S, Peissel B, Barile M, Bonanni B, Viel A, Pensotti V, Tommasi S, Peterlongo P, Weitzel JN, Osorio A, Benitez J, McGuffog L, Healey S, Gerdes AM, Ejlertsen B, Hansen TVO, Steele L, Ding YC, Tung N, Janavicius R, Goldgar DE, Buys SS, Daly MB, Bane A, Terry MB, John EM, Southey M, Easton DF, Chenevix-Trench G, Antoniou AC, Ottini L (2016) Male breast cancer in BRCA1 and BRCA2 mutation carriers: Pathology data from the Consortium of Investigators of Modifiers of BRCA1/2. Breast Cancer Res 18:1-13. https://doi. org/10.1186/s13058-016-0671-y

26. Jylling AMB, Jensen V, Lelkaitis G, Christiansen P, Nielsen SS, Lautrup MD (2020) Male breast cancer: clinicopathological characterization of a National Danish cohort 1980-2009. Breast Cancer 27:683-695. https://doi.org/10.1007/s12282-020-01066-3

27. Deb S, Jene N, Investigators K, Fox SB (2012) Genotypic and phenotypic analysis of familial male breast cancer shows under representation of the HER2 and basal subtypes in BRCA-associated carcinomas. BMC Cancer 12:510. https://doi.org/10.1186/ 1471-2407-12-510

28. Fostira F, Saloustros E, Apostolou P, Vagena A, Kalfakakou D, Mauri D, Tryfonopoulos D, Georgoulias V, Yannoukakos D, Fountzilas G, Konstantopoulou I (2018) Germline deleterious mutations in genes other than BRCA2 are infrequent in male breast cancer. Breast Cancer Res Treat 169:105-113. https://doi.org/10.1007/ s10549-018-4661-x

29. Rashid MU, Muhammad N, Naeemi H, Khan FA, Hassan M, Faisal S, Gull S, Amin A, Loya A, Hamann U (2019) Spectrum and prevalence of BRCA1/2 germline mutations in Pakistani breast cancer patients: Results from a large comprehensive study. Hered Cancer Clin Pract 17:27. https://doi.org/10.1186/s13053-019-0125-5

30. Scarpitta R, Zanna I, Aretini P, Gambino G, Scatena C, Mei B, Ghilli M, Rossetti E, Roncella M, Congregati C, Bonci F, Naccarato AG, Palli D, Caligo MA (2019) Germline investigation in male breast cancer of DNA repair genes by next-generation sequencing. Breast Cancer Res Treat 178:557-564. https://doi.org/10.1007/ s10549-019-05429-z

31. Schayek H, Korach H, Laitman Y, Bernstein-Molho R, Friedman E (2018) Mutational analysis of candidate genes in Israeli male breast cancer cases. Breast Cancer Res Treat 170:399-404. https://doi.org/ 10.1007/s10549-018-4765-3

32. Ding YC, Steele L, Kuan CJ, Greilac S, Neuhausen SL (2011) Mutations in BRCA2 and PALB2 in male breast cancer cases from the United States. Breast Cancer Res Treat 126:771-778. https://doi.org/ 10.1007/s10549-010-1195-2

33. Ottini L, Silvestri V, Rizzolo P, Falchetti M, Zanna I, Saieva C, Masala G, Bianchi S, Manoukian S, Barile M, Peterlongo P, Varesco L, Tommasi S, Russo A, Giannini G, Cortesi L, Viel A, Montagna M, Radice P, Palli D (2012) Clinical and pathologic characteristics of BRCA-positive and BRCA-negative male breast cancer patients: Results from a collaborative multicenter study in Italy. Breast Cancer Res Treat 134:411-418. https://doi.org/10.1007/s10549-012-2062-0

34. Pritzlaff M, Summerour P, McFarland R, Li S, Reineke P, Dolinsky JS, Goldgar DE, Shimelis H, Couch FJ, Chao EC, LaDuca H (2017) Male breast cancer in a multi-gene panel testing cohort: insights and unexpected results. Breast Cancer Res Treat 161:575-586. https:// doi.org/10.1007/s10549-016-4085-4

35. André S, Pereira T, Silva F, Machado P, Vaz F, Aparício M, Silva GL, Pinto AE (2019) Male breast cancer: Specific biological characteristics and survival in a Portuguese Cohort. Mol Clin Oncol 10:644-654. https://doi.org/10.3892/mco.2019.1841

36. Thorlacius S, Sigurdsson S, Bjarnadottir H, Olafsdottir G, Jonasson JG, Tryggvadottir L, Tulinius H, Eyfjörd JE (1997) Study of a single
BRCA2 mutation with high carrier frequency in a small population. Am J Hum Genet 60:1079-1084

37. Syrjäkoski K, Kuukasjärvi T, Waltering K, Haraldsson K, Auvinen A, Borg Å, Kainu T, Kallioniemi OP, Koivisto PA (2004) BRCA2 mutations in 154 Finnish male breast cancer patients. Neoplasia 6:541-545. https://doi.org/10.1593/neo.04193

38. Frank TS, Deffenbaugh AM, Reid JE, Hulick M, Ward BE, Lingenfelter B, Gumpper KL, Scholl T, Tavtigian SV, Pruss DR, Critchfield GC (2002) Clinical Characteristics of Individuals With Germline Mutations in BRCA1 and BRCA2: Analysis of 10,000 Individuals. J Clin Oncol 20:1480-1490

39. Krajc M, Zadnik V, Novakovic S, Stegel V, Teugels E, Besic N, Hocevar M, Vakselj A, De Grève J, Zgajnar J (2014) Geographical distribution of Slovenian BRCA1/2 families according to family origin: Implications for genetic screening. Clin Genet 85:59-63. https:// doi.org/10.1111/cge.12119

40. Gelli E, Colombo M, Pinto AM, De Vecchi G, Foglia C, Amitrano S, Morbidoni V, Imperatore V, Manoukian S, Baldassarri M, Lo Rizzo C, Catania L, Frullanti E, Tagliafico E, Cortesi L, Spaggiari F, Mencarelli MA, Trevisson E, Radice P, Renieri A, Ariani F (2019) Usefulness and limitations of comprehensive characterization of mRNA splicing profiles in the definition of the clinical relevance of BRCA1/2 variants of uncertain significance. Cancers (Basel) 11:1-22. https://doi.org/10.3390/cancers11030295

41. Fraile-Bethencourt E, Díez-Gómez B, Velásquez-Zapata V, Acedo A, Sanz DJ, Velasco EA (2017) Functional classification of DNA variants by hybrid minigenes: Identification of 30 spliceogenic variants of BRCA2 exons 17 and 18. PLoS Genet 13(3):e1006691. https://doi.org/10.1371/journal.pgen.1006691

42. Rizzolo P, Silvestri V, Tommasi S, Pinto R, Danza K, Falchetti M, Gulino M, Frati P, Ottini L (2013) Male breast cancer: Genetics, epigenetics, and ethical aspects. Ann Oncol. https://doi.org/10.1093/ annonc/mdt316

43. Evans DGR, Bulman M, Young K, Howard E, Bayliss S, Wallace A, Lalloo F (2008) BRCA1/2 mutation analysis in male breast cancer families from North West England. Fam Cancer 7:113-117. https:// doi.org/10.1007/s10689-007-9153-9

44. Basham VM, Lipscombe JM, Ward JM, Gayther SA, Ponder BAJ, Easton DF, Pharoah PDP (2002) BRCA1 and BRCA2 mutations in a population-based study of male breast cancer. Breast Cancer Res 4:1-5. https://doi.org/10.1186/bcr419

45. Lubinski J, Phelan CM, Ghadirian P, Lynch HT, Garber J, Weber B, Tung N, Horsman D, Isaacs C, Monteiro ANA, Sun P, Narod SA (2004) Cancer variation associated with the position of the mutation in the BRCA2 gene. Fam Cancer 3:1-10. https://doi.org/10.1023/B: FAME.0000026816.32400.45

46. Woodward AM, Davis TA, Silva AG, Kirk JA, Leary JA (2005) Large genomic rearrangements of both BRCA2 and BRCA1 are a feature of the inherited breast/ovarian cancer phenotype in selected families. J Med Genet 42:2-5. https://doi.org/10.1136/jmg.2004. 027961

47. Tournier I, Brigitte BDP, Sobol H, Stoppa-Lyonnet D, Lidereau R, Barrois M, Mazoyer S, Coulet F, Hardouin A, Chompret A, Lortholary A, Chappuis P, Bourdon V, Bonadona V, Maugard C, Gilbert B, Nogues C, Frébourg T, Tosi M (2004) Significant contribution of germline BRCA2 rearrangements in male breast cancer families. Cancer Res 64:8143-8147. https://doi.org/10.1158/0008-5472. CAN-04-2467

48. Hansen TVO, Jønson L, Albrechtsen A, Andersen MK, Ejlertsen B, Nielsen FC (2009) Large BRCA1 and BRCA2 genomic rearrangements in Danish high risk breast-ovarian cancer families. Breast Cancer Res Treat 115:315-323. https://doi.org/10.1007/ s10549-008-0088-0

49. Rizzolo P, Silvestri V, Ottini L (2017) Retesting BRCA1/BRCA2 mutation negative male breast cancer patients using next generation sequencing technologies. Breast Cancer Res Treat 162:199-200 
50. Rizzolo P, Zelli V, Silvestri V, Valentini V, Zanna I, Bianchi S, Masala G, Spinelli AM, Tibiletti MG, Russo A, Varesco L, Giannini G, Capalbo C, Calistri D, Cortesi L, Viel A, Bonanni B, Azzollini J, Manoukian S, Montagna M, Peterlongo P, Radice P, Palli D, Ottini L (2019) Insight into genetic susceptibility to male breast cancer by multigene panel testing: Results from a multicenter study in Italy. Int J Cancer 145:390-400. https://doi.org/10.1002/ijc.32106
Publisher's Note Springer Nature remains neutral with regard to jurisdictional claims in published maps and institutional affiliations. 